\title{
Degradation of the Bond Strength Between Rebar and Concrete due to the Impressed Cathodic Current
}

\author{
Jiang-Jhy Chang \\ Associate Professor, Department of Harbor and River Engineering, National Taiwan Ocean University, Keelung, Taiwan \\ 202, R.O.C \\ Weichung Yeih \\ Professor, Department of Harbor and River Engineering, National Taiwan Ocean University, Keelung, Taiwan 202, R.O.C \\ Ran Huang \\ Professor, Department of Harbor and River Engineering, National Taiwan Ocean University, Keelung, Taiwan 202, R.O.C
}

Follow this and additional works at: https://jmstt.ntou.edu.tw/journal

Part of the Civil and Environmental Engineering Commons

\section{Recommended Citation}

Chang, Jiang-Jhy; Yeih, Weichung; and Huang, Ran (2009) "Degradation of the Bond Strength Between Rebar and Concrete due to the Impressed Cathodic Current," Journal of Marine Science and Technology. Vol. 7: Iss. 2, Article 3. DOI: $10.51400 / 2709-6998.2526$

Available at: https://jmstt.ntou.edu.tw/journal/vol7/iss2/3

This Research Article is brought to you for free and open access by Journal of Marine Science and Technology. It has been accepted for inclusion in Journal of Marine Science and Technology by an authorized editor of Journal of Marine Science and Technology. 


\section{Degradation of the Bond Strength Between Rebar and Concrete due to the}

Impressed Cathodic Current

\section{Acknowledgements}

The financial support from NSC under contract no. NSC 87-2211-E-019-011 to the National Taiwan Ocean University is highly appreciated. 


\title{
DEGRADATION OF THE BOND STRENGTH BETWEEN REBAR AND CONCRETE DUE TO THE IMPRESSED CATHODIC CURRENT
}

\author{
Jiang-Jhy Chang, ${ }^{*}$ Weichung Yeih** and Ran Huang**
}

Keywords: Cathodic current, bond strength, concrete.

\section{ABSTRACT}

In this study, the degradation of the bond strength between the steel rebar and concrete by the impressed cathodic current was investigated. Experimental results showed that the bond strength degraded as the charging current density and the polarization time increased basically. A new parameter representing the total transferred electrons per unit protected area was proposed, and the bond strength was found to decrease as the parameter increased after some value.

\section{INTRODUCTION}

Although the cathodic protection is a suitable and widely-used method for corrosion prevention of reinforcing steel in concrete, it still presents some problems which remain to be solved. Physical and chemical inhomogeneities and instabilities inherent to the concrete material may lead nonuniform distribution of the cathodic protection currents and result in localized overprotected area $[1,2]$. The hydrogen permeation current for the cathodically protected steel membrane with concrete cover has been reported to increase nonlinearly with the concrete cover thickness [3]. It was studied [4, 5] that the overprotection cathodic current softened the $\mathrm{C}-\mathrm{S}-\mathrm{H}$ gel in concrete, so that both the compressive strength and the durability of concrete could be reduced. It was found that the alkali-silica reaction would be accelerated by the cathodic currents [4]. Also, it was found $[5,6]$ that the bond strength between rebar and concrete decreased due to the cathodic current.

In this study, degradation of the bond strength between rebar and concrete due to the cathodic current was evaluated by conducting the single rebar pullout test. Test variables included cathodic current densities

Paper Received July 5, 1999. Revised September 17, 1999. Accepted October 25, 1999. Author for Correspondence: Jiang-Jhy Chang.

*Associate Professor, Department of Harbor and River Engineering, National Taiwan Ocean University, Keelung, Taiwan 202, R.O.C.

**Professor, Department of Harbor and River Engineering, National Taiwan Ocean University, Keelung, Taiwan 202, R.O.C.
Table 1. Mix design for concrete $(\mathrm{W} / \mathrm{C}=\mathbf{0 . 5 8 3})$

\begin{tabular}{cc}
\hline Materials & Mix proportions, $\mathrm{Kg} / \mathrm{m}^{3}\left(\mathrm{slug} / \mathrm{ft}^{3}\right)$ \\
\hline Water & $204(0.396)$ \\
Cement & $350(0.680)$ \\
Sand & $745(1.448)$ \\
Aggregate & $1024(1.990)$ \\
\hline
\end{tabular}

and polarization periods. It was found that the bond strength decreased as the cathodic current density increased and/or the total polarization time increased. The product of the charging cathodic current density and the total polarization time can be considered as a parameter, which represents the total transferred electrons per unit protected area. It was found that there exists a unified regression curve between the bond strength obtained from different designated variables and the proposed parameter, which is meaningful in corrosion prevention design.

\section{EXPERIMENTAL METHODS}

In this study, Type I Portland cement conforming to ASTM 150-89 [7] was used. River sand and crushed stone were from local sources. The concrete mix design is listed in Table 1. The reinforcing steel was made of medium carbon steel with a Young's modulus of 203 $\mathrm{GPa}(29435 \mathrm{ksi})$ and a yield strength of $410 \mathrm{MPa}(59.5$ $\mathrm{ksi})$. The nominal diameter of rebar was $1.27 \mathrm{~cm} \mathrm{(4/8}$ in) and the details of rebar geometry are given in Table 2.

The pullout specimen was cast in a $\phi 10 \mathrm{~cm} \times 20 \mathrm{~cm}$ $(\phi 4$ in $\times 8$ in) steel mold with reinforcing steel positioned at the center. The embedded lengths of rebars were 4,6 and $8 \mathrm{~cm}$. After demolding, the specimens were cured for 28 days. The compressive strength of concrete at 28 days was $32.8 \mathrm{MPa}(4.76 \mathrm{ksi})$. Then, the pullout specimens were immersed into $3.5 \% \mathrm{NaCl}$ solution. The cathodic current densities applied to the pullout specimens were $0,3,200$ and $600 \mu \mathrm{A} / \mathrm{cm}^{2}$. The polarization times were $0,4,8$ and 12 months. After a 
Table 2. Details of the rebar geometry

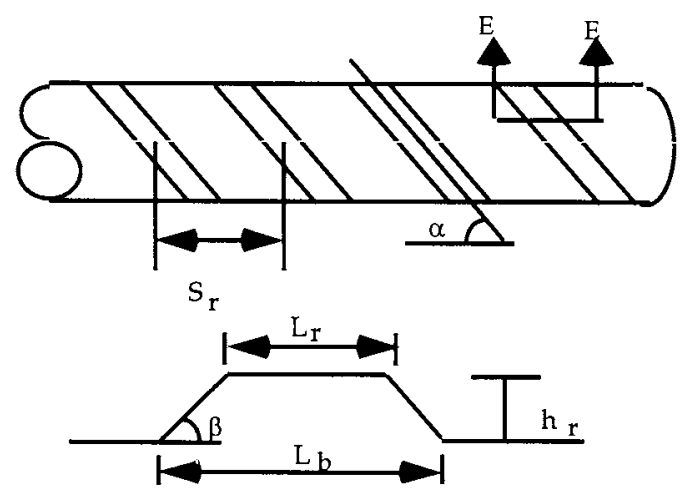

E-E cross section

\begin{tabular}{ccccccccc}
\hline $\begin{array}{c}\text { number of } \\
\text { steel rebars }\end{array}$ & $\begin{array}{c}d_{n}, \text { Nominal } \\
\text { diameter, cm } \\
\text { (in) }\end{array}$ & $\begin{array}{c}\text { Nominal } \\
\text { area, } \mathrm{cm}^{2} \\
\left(\mathrm{in}^{2}\right)\end{array}$ & $\begin{array}{c}\alpha \\
\mathrm{deg}\end{array}$ & $\begin{array}{c}\beta \\
\mathrm{deg}\end{array}$ & $\begin{array}{c}\mathrm{S}_{\mathrm{r}} \\
\mathrm{mm} \\
\text { (in) }\end{array}$ & $\begin{array}{c}\mathrm{L}_{\mathrm{r}} \\
\mathrm{mm} \\
\text { (in) }\end{array}$ & $\begin{array}{c}\mathrm{h}_{\mathrm{r}} \\
\mathrm{mm} \\
\text { (in) }\end{array}$ & $\begin{array}{c}\mathrm{L}_{\mathrm{b}} \\
\mathrm{mm} \\
\text { (in) }\end{array}$ \\
\hline 4 & 1.27 & 1.2668 & 65 & 53.7 & 7.84 & 1.81 & 0.84 & 3.05 \\
& $(0.5)$ & $(0.1964)$ & & & $(.309)$ & $(.071)$ & $(.033)$ & $(.120)$ \\
\hline
\end{tabular}

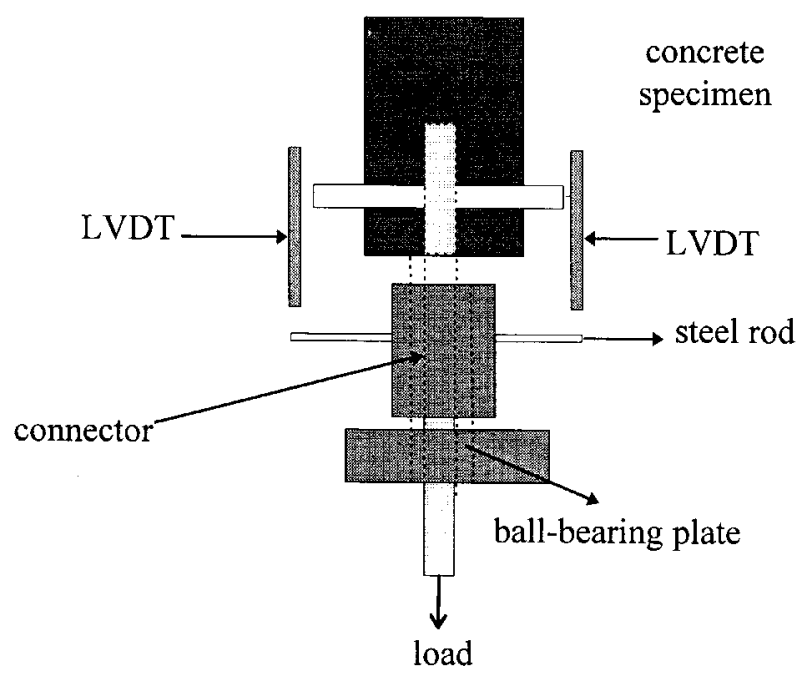

Fig. 1. Pullout measurement setup.

given polarization time, pullout tests were performed on three specimens for each group of a specified embedded rebar length and a given cathodic current density. Pullout test setup basically followed the specification of ASTM C234-91a [8], but the cylindrical specimens were used instead of prismatic specimens. The bearing plate was designed to accommodate the specimens. The pullout test was performed in a universal material testing machine at a maximum stroke rate of $1.27 \mathrm{~mm} / \mathrm{min}$. The maximum pullout forces were recorded, and divid-

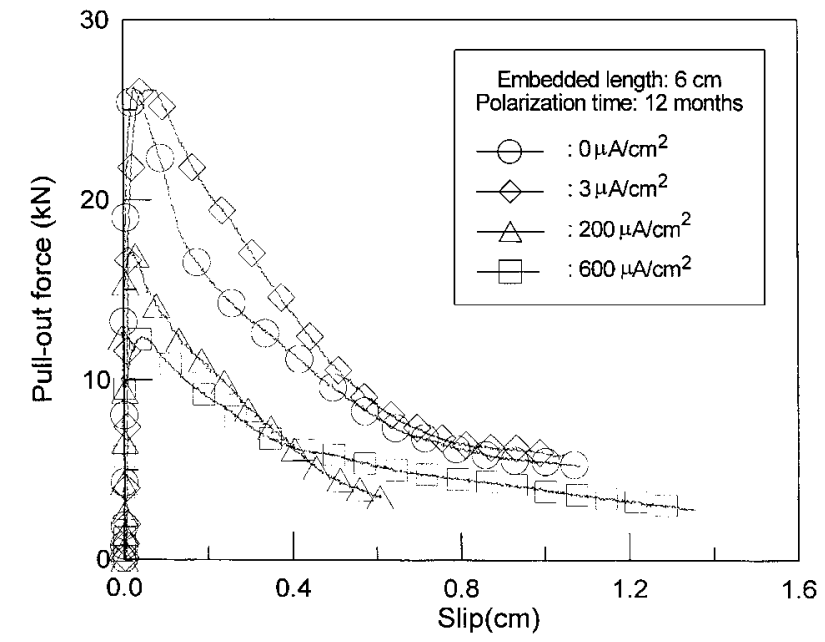

Fig. 2. Typical pullout curves.

ing them by the corresponding embedded area to obtain the bond strengths. The deviation of the bond strengths for specimens of each group was below $9 \%$ and the average bond strength was used for analysis. The setup of measurement equipment is illustrated in Fig. 1.

\section{RESULTS AND DISCUSSIONS}

Typical pullout curves are illustrated in Fig. 2. Basically, we use the average value of three pull-out failure specimens and test results are tabulated in Table 
Table 3. Test results

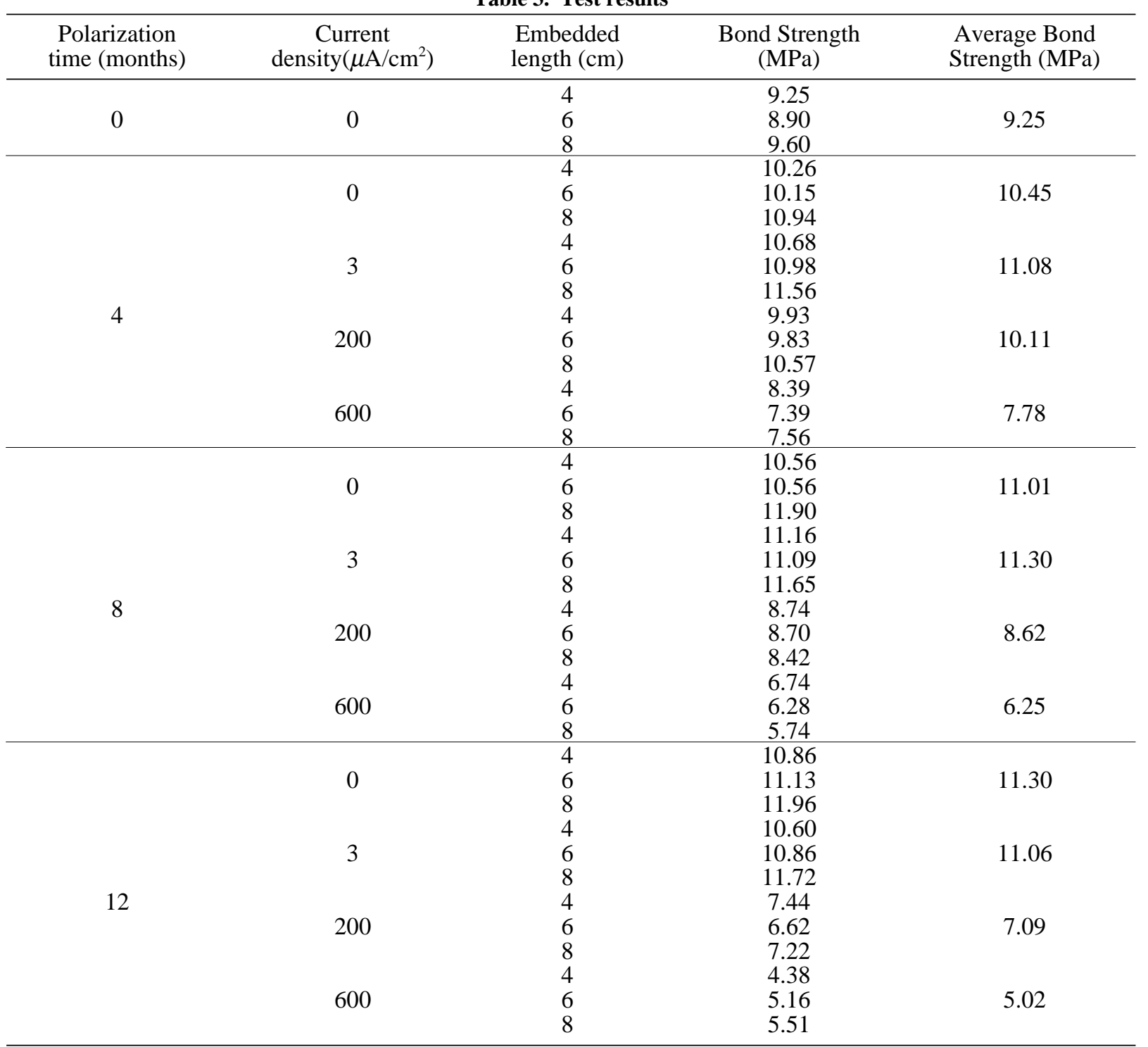

3 and shown in Fig. 3. From the table, it was found that the average bond strength for the control specimens increased slightly as the polarization time increased generally. The continuous portland cement hydration would increase the bond between rebar and concrete. Also after polarization of 4 months and 8 months, the average bond strength of specimens protected by $3 \mu \mathrm{A} / \mathrm{cm}^{2}$ was higher than that of the control specimens $\left(0 \mu \mathrm{A} / \mathrm{cm}^{2}\right)$. Other combinations of cathodic current densities and polarization times did not show the same trend. Nevertheless, for higher cathodic current density and longer polarization time, the degradation of bond strength was more obvious. This may result from the impressed cathodic current effects as follows: (1) the cathodic current provided energy which would enhance the hydration reaction of cement so that the bond strength increased $[9,10]$; (2) the $\mathrm{Na}^{+}$and $\mathrm{K}^{+}$ions would be attracted to migrate to the interface, and the $\mathrm{C}-\mathrm{S}-\mathrm{H}$ gel would be attacked by these ions so that the bond strength decreased $[5,6]$. For $3 \mu \mathrm{A} / \mathrm{cm}^{2}$ protected specimens, the former hydration effect was more apparent than the second effect at polarization times of 4 and 8 months. For other conditions, the ion migration effect was dominant.

The percentage of bond strength reduction versus current density was shown in Fig. 4, the percentage of bond strength reduction was defined as

$$
s \equiv \begin{cases}\frac{\left\|\sigma_{p}-\sigma_{0}\right\|}{\sigma_{0}} \times 100 \% & \text { when } \sigma_{p} \leq \sigma_{0} \\ 0 & \text { when } \sigma_{p}>\sigma_{0}\end{cases}
$$




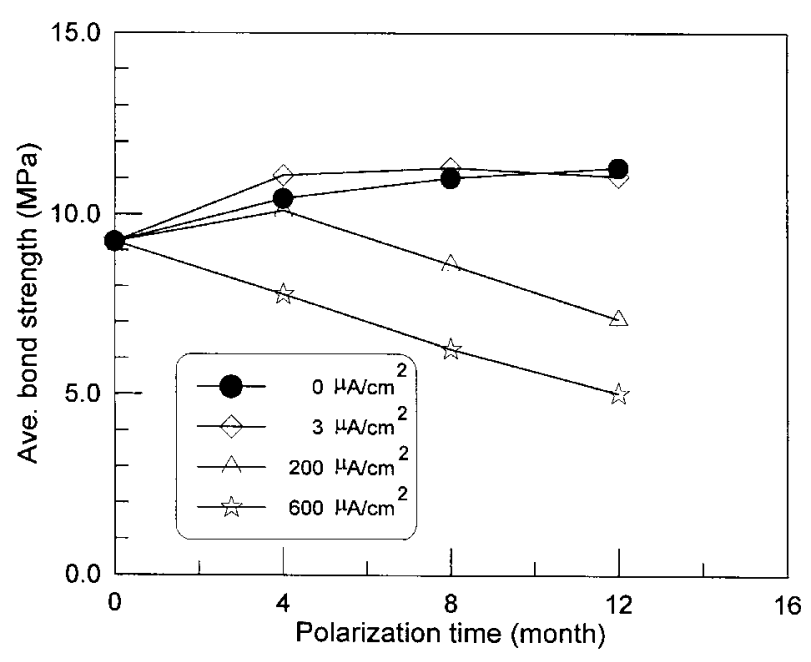

Fig. 3. The average bond strength versus the polarization time.

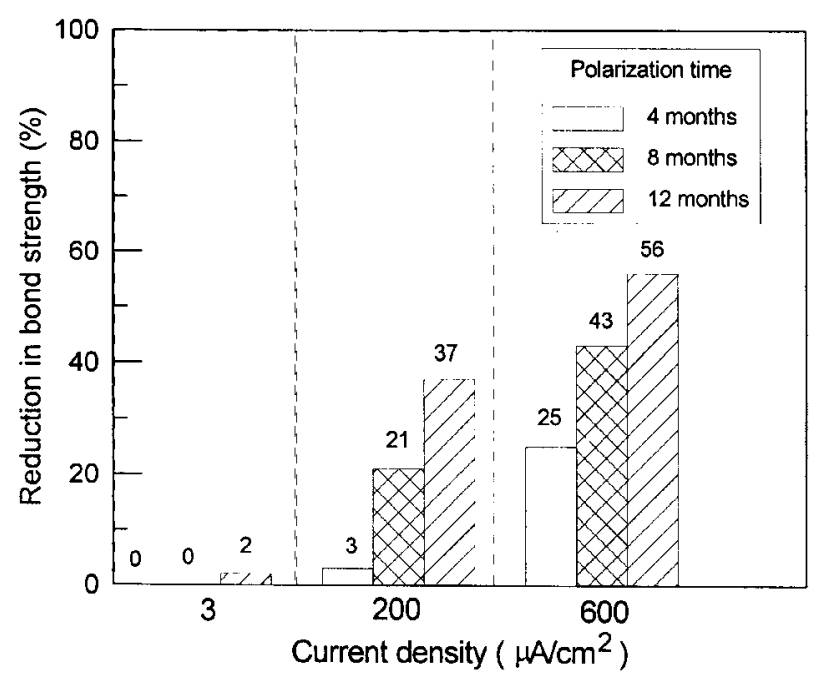

Fig. 4. Bond strength reduction versus current density.

where $s$ is the percentage of bond strength reduction, $\sigma_{p}$ is the bond strength for the specimens at a specific polarization time and $\sigma_{0}$ is the bond strength for the control specimens at the corresponding time. It was found that maximum reduction percentage in bond strength was about $56 \%$.

From test results, it appears that the effect of the current density and polarization time may be combined together. A new parameter, $\psi$, was introduced and $\psi$ is equal to the product of the current density and the polarization time. The bond strength versus $\psi$ diagram is shown in Fig. 5 in which $\psi=i_{C} \times t_{P}$ where $i_{C}$ is the cathodic current density and and $t_{P}$ is is the polarization time. In the figure, small $\psi$ effect is neglected in the regression curve since this behavior stems from the electrical curing as stated above. The regression curve

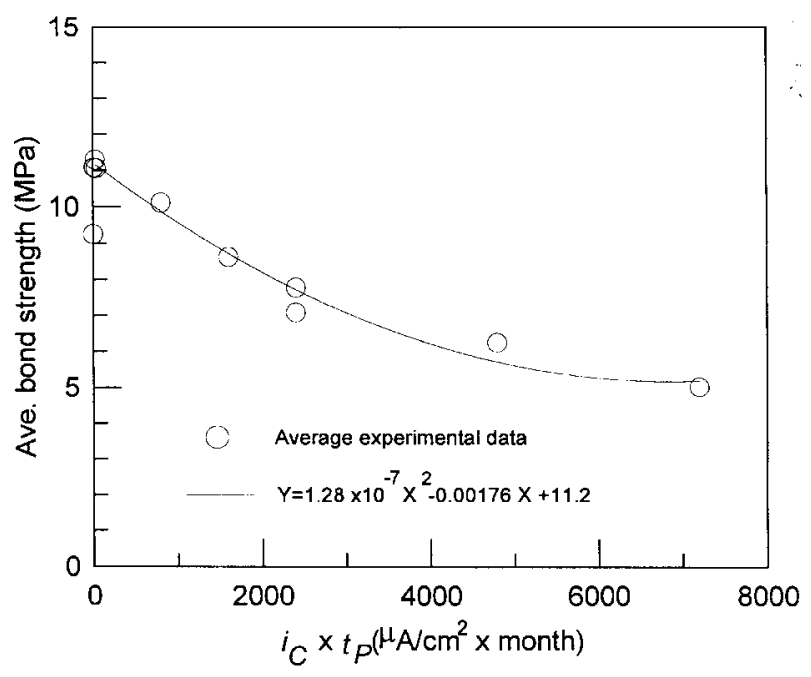

Fig. 5. The average bond strength versus $\psi$.

illustrates that a unified relationship between bond strength and $\psi$ exists. Physically, the bond degradation is mainly induced by the total amount of $\mathrm{Na}^{+}$and $\mathrm{K}^{+}$ions nearby the interface. And the accumulated amount of $\mathrm{Na}^{+}$and $\mathrm{K}^{+}$ions depends on the total transferred electrons during the polarization period. As $\psi$ increased, the amount of $\mathrm{Na}^{+}$and $\mathrm{K}^{+}$ions per unit protected rebar area increased to attack the C-S-H gel nearby the interface and then resulted in the degradation of bond strength. For engineering applications, the curve shows the degradation of bond strength due to the combined effect of the impressed current density and the polarization time. For example, if the current density is chosen as $3 \mu \mathrm{A} /$ $\mathrm{cm}^{2}$ [5], which is the common used current density for an uncontaminated reinforced concrete member, and the required bond strength is $7 \mathrm{MPa}$, then the estimated life will be about 864 months which is equal to 72 years. It should be noticed here that the application of the curve is limited to the cases using the same concrete and under same environment. Nevertheless, this study provides a method for the engineering practices. For different concrete mixes and environments, the empirical curve should be obtained at first. Under a specific environment, a family of curves for different concretes can be obtained experimentally.

\section{CONCLUSION}

The degradation of bond strength between rebar and concrete due to the impressed cathodic current was evaluated by the single rebar pullout test. It was found that the bond strength decreased as the current density and the polarization time increased. A new parameter, $\psi$, was introduced to represent the combined effect of 
the current density and polarization time on the bond strength. This concept is promising for corrosion design for reinforced concrete structures. Further, it was found that a tiny cathodic current might enhance the bond strength in the beginning stage due to the electrical curing effect; the mechanism and quantitative evaluation of such effect is worth being studied.

\section{ACKNOWLEDGMENT}

The financial support from NSC under contract no. NSC 87-2211-E-019-011 to the National Taiwan Ocean University is highly appreciated.

\section{REFERENCES}

1. Wyatt, B.S. and Irvine, D.J., "A Review of Cathodic Protection of Reinforced Concrete," Materials Performance, Vol. 26, pp. 12-21 (1987).

2. Lehmann, J.A., "Cathodic Protection of Reinforced Concrete Structures," Materials Performance, Vol. 26, pp. 79-81 (1987).

3. Chang, J.J., Huang, R. and Yeih, W., "Effect of Concrete Thickness on Hydrogen Permeation Through Cathodically Protected Steel Membranes," Mat. Chem. and Phys., Vol. 49, pp. 16-21 (1997).

4. Ali, M.G. and Rasheeduzzafar, "Cathodic Protection Current Accelerates Alkali-Silica Reaction," ACI Materials Journal, Vol. 90, No. 3, pp. 247-252 (1993).

5. Locke, C.E., Dehghanian, C. and Gibbs, L., "Effect of Impressed Current on Bond Strength between Steel Rebar and Concrete," NACE Corrosion 83, Paper No. 178, Materials Performance and Corrosion Conference, Anaheim, pp. 178/1-178/16 (1983).

6. Rasheeduzzafar, Ali, M.G. and Al-Sulaimani, G.J., "Degradation of Bond between Reinforcing Steel and
Concrete Due to Cathodic Protection Current," ACI Materials Journal, Vol. 90, No. 1, pp. 8-15 (1993).

7. ASTM 150-89. Specification for Portland Cement. ASTM annual book of standards, section 4, construction, Philadelphia (1991).

8. ASTM C234-91a. Standard test method for comparing concretes on the basis of the bond developed with reinforcing steel. ASTM annual book of standards, section 4, construction, Philadelphia (1991).

9. Neville, A.M. Properties of Concrete, $4^{\text {th }}$ edition, Longman Group Limited, England (1995).

10. Bredenkamp, S., Kruger, D. and Bredenkamp, G.L., "Direct Electric Curing of Concrete," Mag. Concr. Res., Vol. 45, No. 162, pp. 71-74 (1993).

\section{陰極防蝕電流對鋼筋與混凝土界面 握裹強度折減之影響}

張建 智葉爲忠黄 然

國立臺灣海洋大學河海工程學系

摘 要

本研究係探討外加院極防蝕電流對鋼筋與混凝 土界面間的握裹強度之折減效應。實驗結果顯示出基 本上隨著外加電流密度與通電時間的增加, 界面握裹 強度的折減就越明顯。本文中並提出一個新的参數, 其代表著在通電時間内單位受保護的鋼材面積上得失 電子總數, 且以這個參數來表示電流密度與通電時間 的合成效果, 而結果顯示當此參數超過某一定值以 後, 握裹強度便開始隨參數的變大而折減越多。 